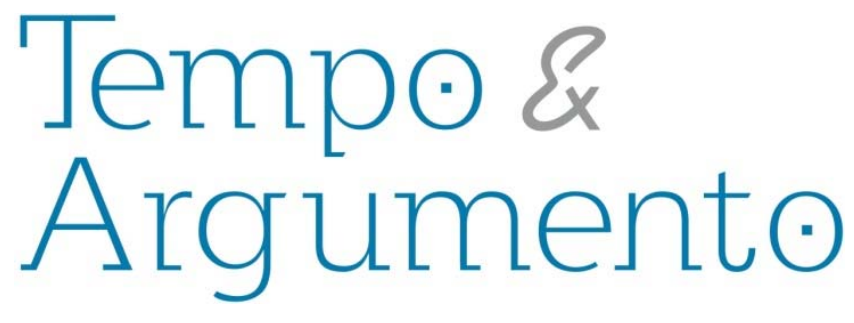

\title{
The Argentine guerrilla and the masses: the ERP and its insertion
}

\begin{abstract}
Between 1959 and 1977, there were more than 17 armed organizations in Argentina. Beyond the success achieved, all of them proposed a combination of armed struggle and popular mobilization. To do this, they tried to carry out the so-called "mass work." Two of them, Montoneros and PRT-ERP, were very successful in "inserting" the organization among the population as a whole. Herein, the insertion of the second of these organizations is addressed, and we postulate that guerrilla as a theme, in Argentina, was much more complex than we assume. In fact, the relationship between guerrilla and popular organization proposes that armed struggle was the result of a historical process and social demands, and not merely a conjunctural fact.
\end{abstract}

Keywords: Argentina; Guerrilla Warfare; Mobilization; Masses.
Pablo A. Pozzi

Professor in the Ph.D. Program in History and Director of the MA Program in Latin American Cultural Studies at the University of Buenos Aires. Argentina. pablo.pozzi@yahoo.com.ar

\section{Translator}

\section{Evandro Lisboa Freire}

Translator and copy editor in English and Spanish. MA in Applied Linguistics (PUC-SP).

Specialist in Translation (UNIBERO). Brazil

elf_translation@yahoo.com.br

\section{To cite this translation:}

POZZI, Pablo A. The Argentine guerrilla and the masses: the ERP and its insertion. Tempo e Argumento, Florianópolis, v. 7, n.16, p. 401 - 420. set./dez. 2015. Original title: La guerrilla argentina y las masas: el ERP y su inserción

DOI: $10.5965 / 2175180307162015401$

http://dx.doi.org/10.5965/21751803071652015401 


\section{A guerrilha argentina e as massas: o ERP e sua inserção}

\begin{abstract}
Resumo
Entre 1959 e 1977, são estimadas mais de 17 organizações armadas na Argentina. Acima do êxito alcançado, todas buscaram combinar a luta armada com aà mobilização popular. Para tanto, tentaram desenvolver $\mathrm{O}$ que se denominou "trabalho de massas". Duas delas, Montoneros e PRT-ERP, obtiveram muito sucesso na "inserção" da organização entre a população como um todo. Aqui, aborda-se a inserção da segunda dessas duas organizações e postula-se que o tema guerrilheiro, na Argentina, foi muito mais complexo do que se supõe. De fato, a relação entre guerrilha e organização popular sugere que a luta armada foi produto de um processo histórico e de reivindicações sociais, e não um mero fato conjuntural.
\end{abstract}

Palavras-chave: Argentina; Guerrilha; Mobilização; Massas.

\section{La guerrilla argentina y las masas: el ERP y su inserción}

\begin{abstract}
Resumen
Entre 1959 y 1977 se contabilizan más de 17 organizaciones armadas en Argentina. Más allá del éxito logrado, todas ellas se plantearon una combinación de lucha armada con movilización popular. Para lograr esto, intentaron desarrollar lo que denominaron "trabajo de masas". Dos de ellas, Montoneros y PRT-ERP, fueron bastante exitosas en lograr la "inserción" de la organización entre la población en general. Aquí se desarrolla la inserción de la segunda de estas dos organizaciones y se postula que el tema guerrillero, en Argentina, fue mucho más complejo de lo que suponemos. De hecho, la relación entre guerrilla y organización popular plantea que la lucha armada fue producto de un proceso histórico y de reivindicaciones sociales, y no un mero hecho coyuntural.
\end{abstract}

Palabras clave: Argentina; Guerrilla; Movilización; Masas.

The Partido Revolucionario de los Trabajadores (PRT) is known to have led the Ejército Revolucionario del Pueblo (ERP), a major Argentine guerrilla group between 1969 and 1977. However, it may not be characterized as a focus (at least according to the classic definition by Regís Debray, 1967), since it had agencies and mass work, legal and trade union fronts, student groups, and publications. In fact, the PRT-ERP was successful in organizing the sugar workers who were traditionally Peronist, from Tucumán and Jujuy, as well as the axemen from the impoverished and conservative province of Santiago del Estero, students and workers from the Catholic and anti-Peronist province of Córdoba, and the leftist students from the National University of Rosario. Although there were never more than a few thousand militants during the decade, the PRT was 
influential in the political culture in the axis Tucumán-Córdoba-Rosario. According to various sources, by 1975 the PRT had cells in more than four hundred major factories in the Greater Buenos Aires; it remained strong in Tucumán, Jujuy, and Santiago del Estero; it succeeded in organizing groups of industrial workers from Cordoba, of metalworkers, meat packers, and petrochemical workers from Rosario; and the Patagonian oil workers. Besides, there were very active groups in the student movement, among cotton tenants from the Chaco and among court officials and teachers from Formosa. Finally, it had managed to establish in many towns in the countryside, such as Río Cuarto, Rafaela, Ceres, San Francisco, General Roca, Neuquén, Junín, Mendoza, Metán, Clodomira, Bahía Blanca, Santa Fe, and Paraná. At its highest point, its clandestine newspaper El Combatiente issued 20,000 copies; there were also publications aimed at specific workers' sectors ${ }^{1}$; and three legal publications, the daily newspaper El Mundo, the weekly magazine Nuevo Hombre, and the weekly political magazine Posición. Despite all this, one of the central themes to be considered -above all for annihilating the organization by $1977-$ is how deep was its insertion among the Argentine masses?

The theme relationship between an organization and the masses is one of the most complexes to discuss. Generally, this is named as the degree of insertion into this or that social sector. Much of the issue lies on the definition of what is implied in "insertion." Another issue has to do with the difference in perspective between the observers and the objectives of the same organization. In this regard, criticizing a student organization for not having any insertion into workers' sectors makes no sense. Thus, it is different weighting the insertion of a revolutionary, clandestine, and board-based party, and that of a legal one, populist and based on the masses. However, it is even more complex to consider the evidence that enable characterizing the insertion degree of an organization. If an organization gathers workers, does this mean it has a good insertion among workers? In turn, if it heads a trade union, or if it could prove to have gained the sympathy of a certain population segment, what does this mean about its insertion?

In our case -the PRT-ERP, a revolutionary, clandestine, and board-based party- we define insertion as an organization's ability to represent popular demands, work along

\footnotetext{
${ }^{1}$ For instance, El Combatiente Telefónico and El Combatiente Metalúrgico.
} 
manages to achieve. The larger number of an organization's militants implies a concrete result of mass work and an improved insertion, but it is not the only one. A successful mass work not only leads to attracting new members, but it mainly increases prestige among the population, generates sympathy and support. The latter is very difficult to measure, because it is in the realm of subjective assessment. Also, potential characteristics of the insertion achieved vary from one organization type to another, contrasting the organizations that do not generate greater commitment or risk to those subject to the vicissitudes of repression. ${ }^{2}$ However, as a general rule we may assess the insertion level of a political organization by considering its growth, the dissemination and reception of its propaganda, its ability to listen and lead various mass sectors, and the attitude of ordinary people towards it.

This does not imply, in any way, that the masses enter the "partido" (even when this is "mass-based"), but there is a relationship between organization and people that allows the first to rely on informal support by the latter. In turn, this should warn us against an idealization type where "the population (or class) supports this or that organization." Both the people and the class are a complex set of individuals, changing from time to time, according to pressure and consciousness. We must also avoid generalization of individual examples. Nevertheless, taking into account the steps needed, what these examples can indicate is that there is some level of sympathy (or not $)^{3}$ and certain levels of informal support. At the same time, it is unlikely that this

\footnotetext{
${ }^{2}$ Clearly, there are times when political participation in a revolutionary organization becomes a fad or a result of adventurism. Because of its inherent characteristics, entering the PRT-ERP was seldom a result of such issues, although there were adventurers in its ranks.

3 "Sympathy" is a very problematic concept, unfeasible and, above all, hard to quantify. However, it is the best concept we have to refer to informal support forms. The complexity of the theme can be seen more clearly if we consider that many of the actions by the ERP generated sympathy, but did not translate into concrete political support. Why this did not happen is a theme that deserves to be analyzed and investigated. Indeed, sympathy is a support form to take into account, but at the same time it reflects a contact with population's feelings and little political development. An example of this was mutual support with militants for the mere fact that they are "young willing people," regardless of the organization to which they belonged and the political cause they pursued. I thank Celina Bonini for this observation.
} 
situation takes place evenly over time and geographical space. In short, the insertion degree of an organization varies according to its political behavior, according to the historical time and how it is perceived by the masses, and, above all, according to the quality of each individual militant. It is perfectly feasible that a militant with an excellent insertion in Córdoba fails to achieve it in Tucumán, or that this insertion is good at the highest point with the mass and weaker at a time of decrease, when the costs of sympathizing with an organization subject to State repression increase.

The case of the PRT-ERP is complex in itself, both due to the organization type and the problem of collecting reliable information and the obstacle that even today, decades later, it raises strong passions and discussions. We must recall that the PRT has always proposed to be a board-based party and not a mass-based one. ${ }^{4}$ The organization took stock of its own development by mid-1974. At that time it estimated that:

... the PRT $[\ldots]$ has today a strong national structure, several thousand active members, several hundred solid boards, struggle tradition and experience [...] But our Partido still faces huge difficulties to effectively fulfill its revolutionary work. This is mainly due to weaknesses regarding organizational insertion into the factory proletariat, weak social composition reaching only 30 percent of factory workers, insufficient professional skill in performing revolutionary tasks, and limited number of organized members. [Santucho, 1974, 45].

That is reason why it is characterized as "a nucleus of the [...] proletarian party for struggle," and not as the party for revolution. And, although the PRT-ERP itself estimated insertion to be insufficient, there was a need to analyze how far this insertion came, which were its characteristics and weaknesses. The PRT-ERP measured its insertion degree almost exclusively by the number of workers recruited. However, this was inconsistent with the fact that the main factor to enter the organization was qualitative and not quantitative: the applicant's political and human qualities were decisive along

\footnotetext{
${ }^{4}$ It should be clear that both are addressed to "the masses" and seek to lead them. The difference between one organization type and another has to do with the structure concerned. A "board-based" party implies that all of its members belong to one of its structures and participate on a regular basis. In this way, they are "professionals of the revolution." In turn, a "mass-board" party divides its individuals into militants (those participating on a regular basis) and affiliates. The first is a quality-based party that focuses on class struggle, while the second is closer to the pattern of electoral parties. It is clear that both aspire not only to lead the masses, but also to incorporate them to the organization.
} 
with the views of his colleagues and neighbors. The assumption was that the organization should have a qualitative growth so that it could influence the mass movement. The number of militants was not the only criterion that reflected an actual insertion. In this way, the significant fact was not how many militants the PRT had in Propulsora Siderúrgica, but their sociopolitical attitude ${ }^{5}$, how workers perceived the PRT, and the production and dissemination of the party's press and propaganda. The key to determine the insertion degree is characterizing the relationship between the organization and the masses.

Through the various documents we may deduce that the main axis of the mass work by the PRT-ERP was the industrial working class, both at the workplace and in the neighborhood, and to a lesser extent marginalized or student sectors. The mass work of the PRT-ERP was uneven at the national level. The various breaks with the 1971-72 "militaristic deviation" had affected more severely regions such as Rosario, Buenos Aires, or La Plata than Córdoba or Tucumán. Likewise, the short period of tolerance (and not of legality), between May and August 1973, also affects the figures available. According to a party's source, within this period El Combatiente issued 21,000 copies, in color, distributed in 15,000 newsstands and 6,000 distributed by militants, while Estrella Roja did the same with 54,000 copies, 40,000 in newsstands and 14,000 by militants (PRT-ERP, 1974, 16). Although this number of copies does not mean that ordinary people read them, or that they agreed with what was proposed by these publications, in fact this amount of copies printed and distributed did compete with any commercial publication. ${ }^{6}$ Once the period of "tolerance" finished, the circulation of both publications decreased by half. In fact, we have partial figures for the distribution and sale of both publications in 1974. The issue 39 (August 26, 1974) of Estrella Roja was distributed as follows: Bahía Blanca (300), Buenos Aires (4,300), Norte-Norte (1,200), Rosario (1,500), Santa Fe (700), Chaco (350), Tucumán (850); leading to a partial total of 9,200. Likewise, the figures for the distribution of the issue 130 (August 14, 1974) of El Combatiente were: Bahia Blanca (250), Buenos Aires

\footnotetext{
${ }^{5}$ By socio-political attitude we mean the specific political and social weight that a militant can have within the workplace.

${ }^{6}$ The publications by the PRT-ERP were not the only ones with this growth. Since 1970, there was a notable boom of leftist publications. In this way, the figures reflect even more the development of the PRT-ERP, both because the growth of its press was late (post 1972) and due to the fact that the society was saturated with publications having political proposals and views in permanent competition.
} 
(3,200), Norte-Norte (330), Rosario (1,600), Santa Fe (500), Chaco (300), Tucumán (600); for a partial total of 6,780 copies. $^{7}$ Of course, distribution and sale do not mean that there were effective readers or that they shared what was proposed by these publications, but it does mean that these people paid the price, reflecting a certain level of support and commitment. We also may not know exactly whether this amount from the press was shared and actually collected and discussed with the reader or simply handed out. ${ }^{8}$

Through this information we can estimate that both the insertion and mass work of the PRT-ERP had a very concrete evolution from its IV Congreso in 1968 to its end as a national organization in late 1977. In the beginning, since its split-off9, during preparations for the IV Congreso, from the sector of Nahuel Moreno and until 1972, its insertion may be characterized as embryonic. It is only since the mid/late 1972 that its insertion may be characterized as widespread and growing, reaching a peak in July 1975, but with little depth. Finally, from late 1975 until late 1977 the weaknesses of the previous insertion are revealed, given the success of repression to destroy the organization by eliminating its structure, cutting its links with mass sectors, and spreading terror among its sympathizers.

From 1968 until late 1972, the mass work and insertion of the PRT-ERP were marked both by internal strives and divisions of the organization and by what was named

\footnotetext{
7 Boletín Interno No. 66, August 20, 1974. Notice that there are no figures for regions such as Córdoba, Santiago del Estero, or Salta. Including these areas, he total is likely to increase by $30 \%$, mainly because Córdoba absorbed a large number of copies. On the other hand, some of the figures indicated may be put into question. For instance, it is unlikely that Rosario distributed more copies of El Combatiente than Estrella Roja. All information available indicate that Estrella Roja was read by much more people and it had a better reception than the party organization. Likewise, in the case of Rosario, where El Combatiente had a greater circulation than Estrella Roja, testimonies indicate they were actually distributed on a political basis. Nevertheless, this is also an indication of some underlying problems. El Combatiente had a greater circulation because readers felt it was "less dangerous" than Estrella Roja, thus it was less compromised. Boletín Interno No. 67, September 11, 1974, reports that, since January 1974 , the national distribution of El Combatiente had increased from 6,360 copies to 11,280, while Estrella Roja increased from 11,400 to 14,330 .

8 According to the testimonies that we managed to gather, there were regions where the press was "handed out," instead of distributed as a political work form. Boletín Interno No. 67, September 11, 1974, reports that it was charged "about $30 \%$ of the total as National propaganda."

${ }^{9}$ In early 1968 a number of differences emerged within the PRT as a preparation for its IV Congreso as a party. Prior to it, there was a division between the group led by Mario Roberto Santucho that named itself as PRT-El Combatiente and the group led by the historical Trotskyist leader Nahuel Moreno, named as PRT La Verdad. Each adopted the name of its newspaper. In 1970, the PRT El Combatiente became the PRT-ERP, while the PRT La Verdad, following its merger with a sector of the Partido Socialista, became the Partido Socialista de los Trabajadores.
} 
insertion of the organization, others such as Córdoba or Tucumán kept an embryonic insertion that tended to grow. However, for the PRT El Combatiente the division had a concrete outcome, because a significant number of people, until then peripheral, decided to join the organization. This incorporation of new members and the development of incipient mass work take place in 1968 and 1969. In a year development is noticed, in addition to La Plata, in areas such as Santiago del Estero, Salta, and Santa Fe, but we keep talking about a small organization that ranged between two hundred and four hundred militants. Nevertheless, internal political disputes erupt again. That occurs along with the first operations carried out since January 1969. On the one hand, there are decreases and incorporation of new members, but on the other hand the organization gets paralyzed again by internalism. This is solved in 1970, with the V Congreso, but at the cost of new divisions, although not as many as that of Morenism. ${ }^{12}$ In 1971, there was a new unfolding, with the addition of more militants, particularly in Tucumán, Córdoba, and Buenos Aires.

This growth slows down between mid-1971 and mid-1972, both due to decrease in a part of the organization's leadership and to emphasis on military activity. Although militaristic deviation seems to have affected to a lesser extent mass work in areas like Córdoba and Tucumán, in other locations, such as Rosario, it implied abandonment of goals pursued. Nevertheless, an even more serious fact was the imprisonment of several of the most important boards of the PRT-ERP, along with emphasis on the military, which involved a lack of political objective and a misunderstanding of mass work. Nevertheless, we must not put too much emphasis on problems arising from leadership in jail. Indeed, within this period, the PRT-ERP boards, most of them with little experience, were looking

10 Luis Mattini characterized the consequences of this deviation as (1) decrease in the top of the organization, but numerical growth in the base, (2) decline of mass work in various regions, (3) political independence of military committees within the organization, (4) increased management verticality, and (5) the inability to take advantage of the 1973 electoral opening (MATTINI, 1990, 115, 117, 118, 123124).

${ }^{11}$ El Combatiente No. 83, July 27, 1973, records the names of 117 political prisoners belonging to the PRT-ERP who were released. In 1972, they might represent around $1 / 3$ of the organization.

12 The 1973 split-offs, named as ERP 22 de agosto and Fracción Roja, were relatively small, although they affected the regions of La Plata and Buenos Aires again. 

and the creation of new party's cells.

Since the escape from the prison at Rawson (August 15, 1972) and Mario Roberto Santucho's return, a few months later, to the country the PRT-ERP reversed the previous tendency under the slogan "ir hacia las masas." During the same period, the organization's growth was remarkable across the country, particularly among working sectors. The weak or almost non-existent regional units from the previous period were reconstructed having a strong mass work as a basis, and both in Córdoba and Tucumán the PRT-ERP became a major political organization. This is even more remarkable considering that the organization was increasingly affected by repression.

The information available allows us to estimate that between mid-1974 and early 1975 the PRT-ERP had cells in each of the main factories in Buenos Aires city and the Greater Buenos Aires. Many of these factory cells published a party's newsletter of their own, such as El Combatiente Metalúrgico, in Dalmine-Siderca, and José Luis Castrogiovanni, in Eaton. ${ }^{13}$ Furthermore, in Córdoba it was one of the main trade union forces and there were cells in Perkins, Grandes Motores Diesel, Fiat Concord y Materfer, ThompsonRamco,, it had a significant presence among workers of Luz y Fuerza and in the executive committee, it co-led the the footwear union, and had achieved organizational levels in all hospitals in the city, in unions like municipal workers, food providers, and teachers, and in many neighborhoods. ${ }^{14}$

In the area of Quilmes, La Plata, and Ensenada the work begun in 1973 had paid off. In YPF, with six thousand workers, there were three cells and the factory newsletter El obrero petrolero was edited. In Astillero Río Santiago there was a squad of the ERP (self-titled as "Los Chacales") and a cell of PRT applicants. There were also PRT cells in the meatworks Swift in Berisso, and a cell of the Juventud Guevarista in Petroquímica

\footnotetext{
${ }^{13}$ El Boletín Interno No. 67, September 11, 1974, reports that the PRT-ERP had 32 factory newsletters.

${ }^{14}$ According to a testimony, "we had such an organized neighborhood that there were two operational houses in the same block."
} 
Sudamericana. Likewise, there was a good work in Peugeot, while in Rigolleau the factory was managed. In Propulsora Siderúrgica

\begin{abstract}
"there came to be between five and seven fellow applicants and activists, and many sympathizers focusing mainly on Sindical. A factory newsletter was published and more than forty El Combatiente were sold within the sections. It was usual to find a worker reading this at his workplace just as a mass circulation newspaper. Here, in addition to trade union influence, the Partido had political influence. How to say it? There were many workers who were neither Peronist or radicals or Communists, they were from the PRT." 15
\end{abstract}

In areas such as Villa Constitución, the PRT-ERP was one of the main forces whose members were among the body of delegates and the executive committee of the local branch of the UOM. The same may be said of metalworkers and Swift in Rosario. Nevertheless, in Tucuman, where according to all accounts it was more difficult to get organized, the PRT-ERP had a strong organization both in sugar mills and at the level of the executive committee of the Federación de Obreros y Trabajadores de la Industria Azucarera (FOTIA) and unions like the Sindicato de Obreros y Empleados Vitivinícolas y Afines (SOEVA). It was also the main force in the National University of Tucumán. In Jujuy there was a strong presence in the executive committee of the trade union of Ingenio Ledesma, where the party's newsletter El Zafrero was edited. In Santiago del Estero there was a good work among students, bus drivers, axemen, and railwaymen. In Mendoza its development took place later and it was

\footnotetext{
"linked to the student movement and the workers' movement from the alcohol-producing area in Maipú, primarily, food in San José de Guaymallén, and the alcohol and oil areas in Luján, where we focus our paper on, there was also work with bank employees, but this activity was a very strong clandestine activity."
}

In Salta, there was a good work conducted with workers and young people in Metán. In Neuquén and in Comodoro Rivadavia cells were established among oil workers and construction workers. There were also groups of college students and cells in many villages and small towns. In the Chaco and Formosa there was an incipient organization

\footnotetext{
${ }^{15}$ Testimony by Daniel De Santis (La Plata, August 28, 1999).
} 

to the local branch of the Federación Argentina de Trabajadores Rurales y Estibadores (FATRE).

In all the above, it may be clear that the PRT-ERP did not unfold in a vacuum. The period had widespread growth of the left-wing as a whole, thus it was likely to face competitors in every location where the organization conducted a mass work. The mere fact that the rather aware and militant workers had many militancy options further highlights the achievement represented by the rapid and varied growth of the PRT-ERP at a national level. Only groups related to Montoneros had a comparable unfolding. In turn, in the left-wing, the Partido Comunista had a stronger presence, but it was the result of half a century of political work. Thus, in a location so saturated with politics as the Argentine Cordovan labor movement in the early 1970s, the PRT-ERP achieved one of its most notable outcomes. ${ }^{16}$ Through the information available, outlined above, it may be deduced that the insertion of the PRT-ERP across the country, between 1972 and 1975, was very varied.

A part of the problem was interconnecting a political attitude that dialectically combined armed struggle and mass work. The actions taken by the ERP during the period favored organization, popularized its name, and generated sympathy among the population. However, this success did not translate into a behavior that could easily enable accumulation and insertion. This behavior was contradictory. For instance, the resolutions of the $\mathrm{V}$ Congreso proposed that "our party should encourage and promote the multiplication of large class-based groups, factory resistance committees [...] the defense of trade unions legality, and the fight for recovery of the working class." A year later (1971), and before the militaristic deviation, this was amended by the guideline:

"The way [...] to achieve a firmly anti-dictatorial orientation in trade unions and mobilize behind them the largest masses is the presence and

\footnotetext{
16 Perhaps one of the most remarkable aspects is that the PRT-ERP in Cordoba, where it faced a strong competition and opposition from the same left-wing, achieved a growth in breadth and depth much greater than in locations where it was almost the only revolutionary option.
} 
growth of our Partido, through armed action of the ERP within the factory and in relation to the trade union struggle, in the creation of cells of our party in factories and other workplaces, and the increasing incorporation of factory workers to the ERP." 17

The same document saw the party's task in the factories as "creating units of the ERP in factories and distributing forces, providing this sector with greater importance." In turn, the pamphlet El Peronismo characterized "armed struggle and, in general, the use of popular violence is the highest form of the class struggle."18 And, in 1973, it consisted in correcting orientation, pointing out a synthesis of both positions, stating there was a need to

"fight for the independence of the trade union movement [...], encourage and strongly support workers' struggle and mobilization for their immediate demands [...], promote a broad legal anti-bureaucratic front [...], maintain and increase [...] the Tendencia Obrera Revolucionaria, which has a clandestine nature, with a program for war and socialism, at the factory level [...]."19

Despite the contradictory political attitude (which enabled each militant to interpret it in his own way), the PRT-ERP conducted, since 1972, an important mass work. Perhaps, the best place where such work has been achieved is Córdoba. Nevertheless, all accounts agree that mass work was quite contradictory: the PRT managed to gather workers and generate sympathy, but it did not go beyond into concrete political influence. Although it was the largest organization in terms of raising willingness, it was not the main organization running the trade union. Here, there may seem that a reversal of the traditional phenomenon in the leftist trade union movement, where workers provided support only within the limits of the factory. In the case of the PRT-ERP, the workers who were gathered by the organization seem to have adhered outside the factory, revealing problems in its trade union policy and the gap between its strategic proposal to take over power for socialism through armed struggle and workers' daily life demands.

\footnotetext{
${ }_{17}$ Resoluciones del Comité Central de marzo de 1971 (DE SANTIS, 1998, 203).

18 Julio Parra. El Peronismo. Ediciones El Combatiente, 1971 (DE SANTIS, 1998, 249).

${ }^{19}$ Resoluciones del Comité Ejecutivo de Abril de 1973 (DE SANTIS, 1998, 376-377).
} 
Clearly, the PRT-ERP had achieved a significant structure and a remarkable insertion among Cordovan workers. This can be seen especially by considering from specific data to rather global elements. For instance, according to the individual in charge of dealing with the trade union front in Perkins, there a hundred copies of El Combatiente were sold, i.e. one out of twelve workers bought it. Just as in Luz y Fuerza, in Perkins the reception was good and the main problem was answering the many questions raised. Another example, already at a different level, was the role of the Movimiento Sindical de Base in the area. The MSB, along with Agustín Tosco and the Partido Comunista, was instrumental in creating the Movimiento Sindical Cordobés that, between 1974 and 1975, effectively led the activity of the Cordovan working class.

The existence of a structure, recruiting new militants, or sympathy of workers' sectors did not necessarily mean that the insertion was that deep. One of the main problems was lack of political experience and militants' unawareness of regional realities. Nevertheless, there was also a problem precisely related to the "party's style." Its militants were references and even very loved and supported. However, its secrecy, on the one hand, and inexperience on the other made it difficult to turn this prestige into a lasting political accumulation. In fact, various respondents among neighbors expressed their love, their support and admiration, but they did not enter the organization and they were not quite sure of its proposals. ${ }^{20}$

An example is father Nelio Rougier, one of the few priests who entered the PRTERP. ${ }^{21}$ Much loved by the people of Barranca Yaco (Córdoba), persecuted by repression, father Rougier was sent to enter the ERP in Monte Tucumano in 1975, where he was killed by the Army. Twenty years later, several neighbors who were interviewed stated he was not dead and might return to the village some day; while others insisted that the security

\footnotetext{
${ }^{20}$ This was not just a problem of the PRT-ERP. Nearly all Argentine Marxists agreed that the working class was evenly Peronist, therefore virulently anti-Marxist. Thus, political practices developed through indirect approaches avoiding an open and direct identification as Marxist. The experience of union leaders like Tosco or Salamanca and the same experience in Santucho, indicate that this assessment was wrong. However, we can only speculate what might have happened regarding the insertion of the leftwing and workers' politicization if mass work had been addressed from an openly Marxist perspective.

${ }^{21}$ Progressive or leftist priests tended to join Montoneros, where they felt no contradiction between their Catholicism and revolutionary Peronism. Montoneros even had a "military chaplain" reproducing the structure of the Argentine Army. However, we did observe some Catholic priests and several Protestant priests who entered the PRT-ERP.
} 
forces had captured and crucified him on an inverted cross. Despite this esteem, it is remarkable that, according to another militant of that cell, the PRT-ERP did not recruit any militant as a result of the work done in that village. This is a problem that will be repeated: even when the insertion was good, the PRT-ERP had trouble to translate it into a lasting political accumulation. Perhaps, much of the problem lies on the fact that the mass work by the PRT-ERP was mainly based on protest. In this way, it had no significant differences from the rest of the left-wing, including the unarmed one. It differed in style and in its relation to the organization's armed actions. The originality, then, resided in the ways of making contact with people and the energy and creativity with which it carried out mass work, but at the same time the organization was unable to link this work to a lasting challenge to the prevalent socioeconomic system. ${ }^{22}$

The above example contrasts with others where insertion was translated into political accumulation, but where the virtues and problems of the PRT-ERP were also revealed in order to get inserted. Two of these cases were the sugar town in San José (Tucumán) and the neighborhood of Villa Libertador (Córdoba). In the first case, several of the neighbors interviewed referred to the PRT-ERP guerrillas as "different," but a comprehensive part of the community, unlike the security forces that were regarded as "outsiders." In the case of Villa Libertador, people remember the guerrilla organization period as one of the best times for the community, when they managed to make a lot of things, and when the police disturbed them too much. ${ }^{23}$ In fact, the PRT-ERP was organized through the local clinic, managing to recruit several neighbors to the

\footnotetext{
${ }^{22}$ The complexity of this problem can be visualized if we take into account that various sectors (workers, slum dwellers, neighbors) approached the left-wing due to concrete problems that the State could not or did not want to solve. The contradiction between immediate needs and interests and the power relations of capitalism became clear, generating an incipient politicization. The left-wing and/or revolutionary Peronism organized people and solved the problem. By solving it, within the framework of the existing system, they eliminated the immediate causes of popular questioning. The problem became how to generate a strengthening of anti-systemic awareness in the process of contacting workers through protests.

23 The PRT-ERP was not the only political organization in Villa Libertador. Vanguardia Comunista and the Montoneros were also organized in the area. The latter grounded their work in the parish and one of the physicians at the clinic that had been established along with militants of the ERP.
} 
organization. Even after the fall of the main militant of the work in the area, the organization was able to retain an insertion up to the eve of the 1976 coup. $^{24}$

Another example of the insertion achieved through a good mass work is the case of Villa Gobernador Gálvez, on the outskirts of Rosario. Gálvez has a strong concentration of workers, particularly in the meat and metal industries, which historically has been Peronist. However, at the same time, it was a location where the PRT-ERP managed to conduct an important mass work that persisted long after the destruction of the organization at the national level. In this case, respondents clearly identified the political organization to which the militants belonged. This implies a very strong identification with militants. In this way, the insertion achieved was very strong, so that the affection and sympathy lead to an unconscious closeness to the militant group. This also implies that not all neighbors had the same attitude, although they make it clear that sympathy for the guerrillas was widespread. Finally, it is worth highlighting the reason why they did not seek to join the organization. It seems they esteemed the PRT-ERP very much, as well as its revolutionary mission, but they did not feel up to par: it was something for "special" people. On the other hand, there also emerges the doubt whether expressing solidarity implied sharing the militants' political attitude. In the testimony it is clear that militants in the area had a very deep support of neighbors in Villa Gobernador Gálvez. The doubt that still remains is whether there was not any other popular militant, with similar human qualities, regardless of belonging to the PRT-ERP or not.

As in the case of Barranca Yaco and Villa Libertador, in all testimonies the theme fear of repression is repeated. The difference is the fact that in the case of Gálvez, the work of the PRT-ERP managed to achieve a deep insertion so that people protected militants despite the intensity of repression. And what will eventually destroy that insertion is not such a repression in the area, but the destruction of the guerrilla organization at the national level. On the other hand, it is noteworthy how in a working area that is strongly Peronist the PRT-ERP managed to have such a significant presence, which almost excluded other armed organizations. For instance, according to various

\footnotetext{
24 The doctor was killed in a road accident after participating in the takeover of the Fábrica Militar de Explosivos in Villa María, on August 10, 1974.
} 
testimonies, the Montoneros never managed to have more than two basic units in the area, "but it brought students to meet their needs." Instead, neighborhoods were generally controlled by the PRT-ERP through a strong presence in the executive committees. This local presence was dialectically related to the strength of the PRT-ERP in meatworks (particularly Swift, Sugarosa, and Paladini) and metallurgical factories in the area. In fact, the trade union of meat packers "El Toro," which had about 150 activists, was driven by militants of the guerrilla organization. According to one of these activists, the reason for this insertion was the fact that

\begin{abstract}
"the PRT had [...] a simple message, which people understood, i.e. "here are the poor and here are the rich.' I think this message was very simple for people. This whole area had a lot of work of the PRT. Every two houses had some contact."25
\end{abstract}

Clearly, the insertion of an organization was something very complex, since politics had to be related to feelings; in the words of the Vietnamese (very cited by the PRT-ERP) there was a need to win people's hearts and minds. This task required not only experience, but also a special quality of the militant. In the locations where militants of the PRT managed to interconnect the various levels achieved a significant insertion of the organization. Sometimes, the insertion was done even contrary to the practice of colleagues in the organization themselves. Winning workers' hearts and minds implied a quality of the militant in terms of the human aspect, but also clarity in terms of combining struggle forms and avoid confusing combativeness and consciousness. At the same time, there was a continued problem in terms of the tendency to replace mass activity with actions of the ERP. Not only the insertion could be weak, but military activity could generate people's rejection. The latter leaves unanswered a number of key questions about the development of consciousness among the Argentine people and its relationship with activity for a revolutionary change, as well as whether the methods applied were the best suited to the objectives.

\footnotetext{
${ }^{25}$ What is meant by "simple message" has much to do with the party style of the PRT-ERP and this is one of the keys to understand how quickly its insertion with a very uneven depth took place.
} 
On the other hand, the same internal documents of the organization indicate its priorities for distributing boards and the problems this could cause. In early 1975, the PRTERP distributed a recommendation to the zonal and regional offices, "in order to maintain harmonious development," defining "the following approximate percentage distribution of fellows by task type: Military 30\%, Trade union 15\%, Advertising 15\%, Student 15\%, Legal 10\%, Organization (Office) 10\%, Youth 5\%."26 The first thing to highlight is that most militants were not assigned to military tasks. But at the same time it is noteworthy there was a recommendation that only $45 \%$ of the total were assigned to mass work (Trade Union, Student, Legal, and Youth), while apparatus tasks (Propaganda and Organization) absorbed $25 \%$ of the actions. However, it is even more remarkable, for a party that claimed to be a part of the proletariat, that no political criterion was set for such a distribution equating the importance of task with regard to the working class (Trade Union) and the students' class, and both with regard to Propaganda. On the one hand, people assigned priority to political work with the working class; on the other, this was contradicted by the distribution of boards.

Here, we must briefly consider some rather crucial problems in terms of mass work of the PRT-ERP by having three levels in mind. The first is militant's. At this level, youthfulness and inexperience of many, along with the leftist tradition, led to confusing combativeness and consciousness and sympathy and commitment. Faced by repression, sectors showing their sympathy, or those almost thoughtlessly combative, retreated and left the activists without a social support that enabled them to continue their work. So, why the organization, and not only the individual militant, did not visualize this? Here lies much of the leadership weakness in the PRT-ERP. While the political attitude of the organization proposed there was a need to listen to the masses, the reality was very different. The view of itself held by the leadership of the PRT, the concept that the party represented the ideology of the proletariat, the quasi-positivist tradition that the organization could not make mistakes, the concept of class struggle within the party, everything is mixed together so that the direction hardly listened to the bases, thus the criticism and feelings of the masses were not noticed or understood. Political leadership

\footnotetext{
${ }^{26}$ Boletín Interno 76, February 22, 1975.
} 
can fulfill its task successfully to the extent that it allows the base to be a drive belt from the masses towards the direction and vice versa. In the PRT-ERP this was blocked due to its very ideological evolution and the cultural structure that had developed from 1968 onwards, which was exacerbated by the very youthfulness of its members. The surprising thing is that the PRT-ERP had achieved a good insertion in many of the locations where this was proposed, despite lacking militants experienced in mass work.

The second level was repression itself. This was focused on the links between the PRT and the masses. Union representatives, neighborhood activists, student leaders were the favorite targets of repression. For instance, to eliminate the weight of the PRT among Tucuman students, the "forces of order" dynamited the dining hall. It managed to get rid of a place for meeting and concentration, hindering the interconnection between militants and the various mass sectors.

Finally, let us consider a serious problem in terms of achieving a good insertion. The PRT-ERP, in 1968, was a small organization. In this regard, it sent the best boards to open works in various areas. This led the zonal offices to rarely correspond to boards in the same area, and this caused difficulties and problems with local militants, hindered training and promotion, and prevented a regional office to gain a deep knowledge of the area. For instance, in Mendoza, in 1975, most of the regional leadership was from Córdoba. This continued boards' turnover prevented any of them to settle, develop a long-term work, and consolidate the existing work. In locations where this did not took place, as in Córdoba or Rosario, and later in Buenos Aires, mass work depth and quality was remarkable.

What can be noticed is that while the work of the PRT left a certain feeling of sympathy, its contribution to the politicization of the entire Argentine people faced concrete limits, since it was never enough to make the qualitative leap that implies deep investigation of the prevailing social system of economic relations. Except in Tucumán and Gálvez, many residents do not remember clearly to which organization the guerrilla belonged in each zone, and they rarely referred to deeper changes: even when expressing admiration, they did that by using the official terminology and resignifying it to speak of "subversive" or "terrorist" individuals. It is remarkable that, twenty years 
later, these neighbors do not remember whether they were afraid of the guerrilla, although they did fear repression. Everyone expressed fear of violence, lack of knowledge about the political guerrilla and various sympathy forms ("they had good intentions;" "someone finally stood up;" "they were daredevil dudes;" "I wish I had helped then"). In some cases, they even said to remember that the guerrilla helped and protected the community from the security forces. Clearly, these reminiscences express that the guerrilla phenomenon has been reinterpreted in memory. However, this does not mean that the feelings expressed are made up or a product referring exclusively to the present. It is much more likely that this memory is based on feelings of that time. This means that the insertion degree achieved by the PRT-ERP was remarkable and broadbased, since it has managed to remain in the popular memory. Nevertheless, at the same time, it was not that deep, since the same memory links the guerrilla to protest and it rarely makes the leap into politics.

\section{Interviews}

88 former members of the PRT-ERP were interviewed and 20 neighbors in areas where the organization pursued its activities. Militants' interviews were formatted as "life history" with cross-examination. Neighbors' interviews were thematic, aiming to evoke memory and trigger subjectivity. Interviewees' names are not informed, particularly to ensure safety.

\section{References}

DEBRAY, Regis. Revolution in the Revolution? New York: The Grove Press, 1967.

DE SANTIS, Daniel (selección). A Vencer o Morir. PRT-ERP Documentos. Buenos Aires: Eudeba, 1998.

MATTINI, Luis. Hombres y mujeres del PRT-ERP. Buenos Aires: Editorial Contrapunto, 1990.

PRT-ERP. Anteproyecto de resolución sobre internacional, In: Hacia el VI Congreso 1974. Mimeo.

SANTUCHO, Roberto Mario [sic]. Poder burgués y poder revolucionario. , 23 de agosto de 1974. 
Received on June 9, 2015 Approved on September 9, 2015

Universidade do Estado de Santa Catarina - UDESC Programa de Pós-Graduação em História - PPGH Revista Tempo e Argumento Volume 07 - Número 16 - Ano 2015 tempoeargumento@gmail.com 